\title{
Preface
}

\section{To an Unknown Reader}

It is difficult today from the perspective of two years to contemplate the genesis of these poems.

We look at them in astonishment, powerless before their strangeness. It's as if we were meeting old friends after years of separation. They are known but foreign because of an impassible chasm-time and distance. Words spat out in a fever, screamed poems, now sound like weak whispers, almost inaudible. Experiences that we tried to reproduce in all their horrible reality have slipped into pallid outlines, already almost erased.

When we look at them right in front of us, the images come again: inscriptions upon the walls of prisons and camps, scrawled

From the collection Spiew Za Drutami (Song behind barbed wire), published in 1947 in tiny limited editions by the Association of Friends of Our Tribune, a Polish Jewish daily newspaper. 
at the last moment by people who had already died. Cries for help, calls for revenge, a sentence terminated at midpoint, maybe only a name and a date, the terror of those days marked clumsily by a weakening hand upon a hard indifferent wall. Today only half-readable traces remain.

These poems are exactly that: inscriptions on a prison wall. They are feeble efforts to preserve a record. Why make such an effort to leave behind a trace and to transmit one's experience before it is all over? What forced us to do this? Was it the pain or was it a protest against the absolute end of things?

No. Having been taught by machine guns to think in categories of thousands and millions, we had reconciled ourselves to the unimportance of the individual. Did we write in order to transmit information and thereby incite people to later vengeance? No. In those days we understood the complete futility of trying to match any punishment to this crime.

And yet we did write for people in the future as an act of selfdefense. We wanted others to discover in our suffering a meaning and a purpose: to ensure that millions did not die in vain as long as our experience was used as a warning for future generations.

These poems, and thousands of other creations, form one cry only: "Remember."

Henia Karmel and Ilona Karmel

Stockholm, April 1947

Translated by Arie A. Galles

Preface xvi 